\title{
Oral Administration of Citrus Extracts in Suckling Piglets
}

\author{
Lidiane Pescke Pereira ${ }^{1}$ \\ https://orcid.org/0000-0003-3625-3299 \\ João Otávio Hilgemberg ${ }^{1 *}$ \\ https://orcid.org/0000-0001-6248-1717 \\ Charlise Primieri ${ }^{1}$ \\ https://orcid.org/0000-0002-6486-5009 \\ Anna Paula Holzmann Mass ${ }^{1}$ \\ https://orcid.org/0000-0003-3149-9943

\section{Cheila Roberta Lehnen ${ }^{1}$ \\ https://orcid.org/0000-0001-5857-8305}

Ponta Grossa State University, BioModel research group, Animal Science Department, Ponta Grossa, Brazil

Received: 2018.09.24; Accepted: 2019.07.08.

*Correspondence: joao.hilgemberg@outlook.com; Tel.: +55-42-3220-3081 (J.O.H)

\section{HIGHLIGHTS}

- Restrictions on the use of antibiotics promote the search for alternatives to its use.

- The use of citrus extracts for piglets was studied

- The addition of citrus extract did not improve the performance of sows and piglets.

- Citrus extract alters intestinal morphology and reduces diarrhea in piglets

Abstract: An experiment was conducted to evaluate the performance of suckling piglets subjected to oral administration of citrus extracts (CE). Twenty sows were used with ten sucking piglets on average initial weight of $1.26 \mathrm{~kg}( \pm 0.32)$ for 21 days. The experimental design was a randomized complete block design with two treatments: Negative Control (without antimicrobials) and Citrus Extracts (ascorbic acid + flavonoids, oral administration of $0.3 \mathrm{mg} \mathrm{kg}$ of BW via pigdoser) with ten repetitions each. The number of live-born piglets in females PO5 was $21 \%$ higher than in PO3 sows. Sows where piglets received CE showed a $10 \%$ higher $(P<0.05)$ feed intake in the last week of lactation. From 8 to 21 days, the feed conversion of NC sows was 23 and $38 \%$ lower $(P<0.05)$ than sows where piglets 
received CE. Piglet mortality was $13.4 \%$ in NC group and $3.9 \%$ in CE group in a single dose on the third day of life. The villous length in the duodenum was $24 \%$ higher $(P<0.01)$ in piglets receiving $C E$. The administration of $C E$ increased $19 \%(P=0.02)$ the villous length of the ileum region of suckling piglets. Frequency of normal feces was higher $(P<0.05)$ in piglets CE group. Oral administration of CE containing flavonoids and ascorbic acid to suckling piglets not improves the piglet growth. However, it alters the gut morphology, and reduces the frequency of diarrhea during suckling period. Parity order interferes on feed intake, feed conversion of sows and performance of litters.

Keywords: ascorbic acid, additives, antibiotics flavonoids, gut health.

\section{INTRODUCTION}

Neonatal diarrhea in suckling piglets causes losses and high costs due to impairment of piglet growth and increased use of medications. These diarrheas have multifactorial causes such as hygiene conditions, prophylactic program in pig herd, the presence of pathogens in the environment and the immune response of the piglets after birth. Susceptibility of newborn piglets contributes to the bacterial development of Escherichia coli and Clostridium spp. in the intestine, leading to imbalance of the enteric microbiota, allowing the colonization, proliferation and production of toxins. The main signs are diarrhea of pasty or liquid consistency and yellowish coloration, dehydration, prostration, high morbidity and mortality of the piglets.

In contrast, the search for healthy food and residue-free has made that laws to regulating the use of antibiotics as growth promoters in farm animals more stringent [1]. This regulation is due to the possible residues left in the final products, which is possible to develop cross-resistance in humans [2]. However, the withdrawal of antibiotics in the suckling phase has a negative effect on piglets, so alternatives has been adopted to replace antibiotics. Studies have shown that plant extracts promote antimicrobial and antioxidant actions, improve the intestinal functions of suckling piglets [3-5].

Among the herbal extracts, the citrus extracts that are rich in flavonoids and ascorbic acid. Ascorbic acid may be present in foods in two ways, the reduced form, so called to ascorbic acid and the oxidized form termed dehydroascorbic acid [6]. It acts on the red blood cells formation in the blood and on the iron absorption and utilization, besides maintaining the integrity of the walls of the blood capillaries [7]. As an alternative method for the use of antibiotics, this work was conducted with the objective of evaluating the effects of oral administration of citrus extracts on suckling piglets.

\section{MATERIAL AND METHODS}

The experiment was carried out in a commercial farm in Toropi City, Rio Grande do Sul State, Brazil. The temperature in the experimental period was $25.0^{\circ} \mathrm{C}$ and relative humidity of $50 \%$. Twenty lactating sows of commercial breed from different parity orders (range one to eight) were used, containing ten suckling piglets on average each. Sows were housed in maternity cages, equipped with feeders and automatic drinkers. In the creep for the piglets has heating plates. The experimental period was 28 days (seven days prepartum and 21 days of lactation). The experimental design was a randomized complete block design with two treatments: Negative Control (NC) (without oral administration of antimicrobials in piglets) and Citrus Extracts (CE) (single dose, oral administration of $0.3 \mathrm{mg} . \mathrm{kg}-1$ of citrus extracts). On the third day of life, was administered orally (pigdoser) $1 \mathrm{~mL}$ of citrus extract solution on dosage of $0.3 \mathrm{mg} . \mathrm{kg}-1$ for each piglet, and negative control piglets was administered orally $1 \mathrm{~mL}$ of potable water, both in single dose. Citrus extracts were added to the vehicle, constituting $50 \%$ of the product and on concentration of $750 \mathrm{mg} / \mathrm{kg}$ of ascorbic acid and bioflavonoids. In each treatment the sows were distributed in two blocs PO3 (four sows) and $P O \geq 5$ (six sows). Each treatment had ten repetitions, being considered a 
repetition the sow and its litter. After the farrowing, the litters were homogenized in size $( \pm$ 10 piglets) and approximate weight of 1.28 quilograms.

Lactating sows received isonutritive diets formulated according to the nutritional requirements of NRC (1998) adjusted based on maize dry matter at $12 \%$ moisture. Sow's diets were composed of high moisture corn (64.4\%), deactivated whole soybean meal $(16.0 \%)$, roasted soybean meal $(16.0 \%)$, vitamin, and mineral premix (3.6\%). The sows were free access to the water and the feed was offered four times a day. From the seven days of life, the piglets received commercial starting feed. The measured and estimated variables in the sows were: (a) feed intake (b) feed conversion of sows, considering the average daily feed intake and litter daily gain; (c) backfat thickness measured with Renco Lean Meater ultrasound at $6.5 \mathrm{~cm}$ from the lumbar midline from the last rib on both sides [8]. The variables measured and observed in piglets were: (a) litter weights, (b) daily piglet weight gain, mortality rate, among piglets killed by starvation and diarrhea in relation to initial population of treatment, divided by total piglets in each treatment. (c) feces consistency, checked daily, using a normal, pasty and liquid classification score and (d) villus height of duodenum, jejunum and ileum. In case of diarrhea, no therapeutic treatment with antibiotics or citrus extract was applied on the piglets.

At the end of the experiment, 20 piglets (one animal randomly selected from each replicate) were euthanized with a combination of $40 \mathrm{mg} / \mathrm{kg}$ ketamine and $20 \mathrm{mg} / \mathrm{kg}$ xylazine, intramuscularly. After euthanasia, $10 \mathrm{~mL}$ of $20 \%$ potassium chloride was administered intramuscularly and samples of small intestine (duodenum, jejunum and ileum were collected. Samples were opened by mesenteric border, stretched through serosa layer and fixed in $10 \%$ buffered formalin solution during 24 hours. Then they were washed in run water and $70 \%$ ethyl alcohol for releasing the excess of fixation solution. For dehydration, washings in graded (from 70 to 100\%) alcohol series were done. Diaphanization was done in xylene before embedding in paraffin. Microtomy was done for obtaining from 12 to 14 semi-serial cuts of $5 \mu \mathrm{m}$ of each segment per animal. Eosin hematoxylin was used for staining. Six measurements were obtained for each sample per piglet. Morphometric analysis of intestinal epithelium was carried out at Laboratory of Histology and Morphology, Santa Maria Federal University (UFSM), Santa Maria City, Rio Grande do Sul State, Brazil. The data were submitted to analysis of variance by GLM procedure at a level of $5 \%$ of significance. The parity order and treatments were considered in the statistical model. Any differences between the means were compared by the Tukey test. For the feces score of suckling piglets, the Chi-square test was used at the $5 \%$ level of significance through the statistical program SAS [9]. The other statistical analyzes were performed with the Minitab 15 statistical program [10].

\section{RESULTS AND DISCUSSION}

Feed intake, feed conversion and backfat thickness of lactating sows where the piglets that received citrus extracts via pig doser or no additive its presented in Table I. The number of piglet's total born and alive did not differ $(P>0.05)$ between treatments. The number of live-born piglets in $\mathrm{PO}>5$ sows was $21 \%$ higher than in $\mathrm{PO} 3$ sows. However, after the births, the litters were homogenized in initial body weight and piglet's number by litter. Feed intake of sows don't differ between parity orders $(P>0.05)$. Sows where piglets received Citrus Extracts $(E C)$ showed a $10 \%$ higher $(P<0.05)$ feed intake in the last week of lactation. This behavior is not associated with the use of citrus extracts in piglets, but to the larger size of litters of the sows of this treatment. However, feed intake between PO3 and PO>5 sows did not differ $(P>0.05)$ during lactation. In this respect, the main impact on feed intake is associated with the intake ability and live weight of the animal. In general, sows are considered adult in the third farrowing, so both body weight and intake capacity are similar to fifth and sixth parity sows [11]. Moreover, this similarity can be observed in the backfat thickness between $\mathrm{PO} 3$ and $\mathrm{PO}>5$ sows (Table 1). From 8 to 21 days, the feed conversion of Negative Control $(\mathrm{NC})$ sows was 23 and 38\% lower $(P<0.05)$ than sows where piglets received citrus extracts. This result is associated to the lower feed intake by females and 
greater daily weight gain of the NC group, indicating higher productive efficiency. This result is associated to the lower feed intake by sows and greater daily weight gain of the NC, indicating higher productive efficiency. However, the Backfat thickness (BT) of the lactating sows did not differ $(P>0.05)$ for parity order. There was greater loss $(-1.7 \mathrm{~mm})$ of BT during lactation in sows of the CE group. The loss of $1.7 \mathrm{~mm}$ is considered normal and does not have negative impacts on the subsequent gestation of sows. Additionally, the higher feed by sows from EC group minimized the fat mobilization. Overall, sows in this study had BT below that recommended by [12], which indicates that there were important tissue losses at the beginning of the productive life of the sows.

Table 1. Feed intake, feed conversion and backfat thickness of lactating sows where the piglets that received citrus extracts via pig doser or no additive.

\begin{tabular}{|c|c|c|c|c|c|c|}
\hline & \multicolumn{2}{|c|}{ Treatments $(\mathrm{T})$} & \multicolumn{2}{|c|}{ Parity order (PO) } & \multicolumn{2}{|c|}{ Probability $^{1}$} \\
\hline & NC & CE & PO3 & >PO5 & $\mathrm{T}$ & $\mathrm{PO}$ \\
\hline No. of sows & 10 & 10 & 8 & 12 & & \\
\hline \multicolumn{7}{|l|}{ No piglets } \\
\hline Total born & $13.4 \pm 0.61$ & $12.4 \pm 0.71$ & $13.1 \pm 0.65$ & $14.5 \pm 0.82$ & ns & ns \\
\hline Born alive & $10.4 \pm 0.40$ & $10.4 \pm 1.36$ & $9.5 \pm 0.81$ & $11.5 \pm 0.72$ & ns & * \\
\hline $\begin{array}{c}\text { After } \\
\text { cross-foster }\end{array}$ & $10.4 \pm 0.24$ & $10.2 \pm 0.58$ & $10.0 \pm 0.70$ & $10.4 \pm 0.22$ & ns & ns \\
\hline \multicolumn{7}{|l|}{$\mathrm{ADFI}, \mathrm{kg}^{2}$} \\
\hline d 1 to 7 & $6.19 \pm 0.08$ & $6.07 \pm 0.22$ & $5.97 \pm 0.24$ & $6.23 \pm 0.10$ & ns & ns \\
\hline d 8 to 14 & $8.08 \pm 0.13$ & $8.27 \pm 0.17$ & $8.10 \pm 0.14$ & $8.28 \pm 0.17$ & ns & ns \\
\hline d 15 to 21 & $7.69 \pm 0.13$ & $8.48 \pm 0.27$ & $7.93 \pm 0.14$ & $8.28 \pm 0.46$ & * & ns \\
\hline \multicolumn{7}{|c|}{ Feed conversion 3,4} \\
\hline d 1 to 7 & $2.88 \pm 0.21$ & $3.14 \pm 0.20$ & $2.89 \pm 0.25$ & $3.09 \pm 0.18$ & ns & ns \\
\hline d 8 to 14 & $3.62 \pm 0.27$ & $4.46 \pm 0.20$ & $4.02 \pm 0.21$ & $4.06 \pm 0.34$ & * & ns \\
\hline d 15 to 21 & $3.49 \pm 0.19$ & $4.84 \pm 0.33$ & $4.01 \pm 0.27$ & $4.28 \pm 0.46$ & * & ns \\
\hline \multicolumn{7}{|c|}{ Backfat thickness, mm } \\
\hline Prepartum & $15.3 \pm 1.50$ & $14.2 \pm 0.37$ & $14.3 \pm 0.47$ & $15.0 \pm 1.26$ & ns & $\mathrm{ns}$ \\
\hline At farrowing & $15.2 \pm 1.24$ & $13.6 \pm 0.40$ & $14.6 \pm 0.55$ & $15.0 \pm 0.95$ & ns & ns \\
\hline d 2 to 7 & $15.3 \pm 0.98$ & $13.7 \pm 0.73$ & $14.0 \pm 0.77$ & $14.4 \pm 0.98$ & ns & ns \\
\hline d 8 to 14 & $15.9 \pm 1.03$ & $13.1 \pm 0.79$ & $14.5 \pm 0.61$ & $14.5 \pm 1.28$ & ns & ns \\
\hline d 15 to 21 & $15.5 \pm 0.74$ & $12.5 \pm 1.04$ & $14.1 \pm 0.35$ & $13.7 \pm 1.31$ & * & ns \\
\hline
\end{tabular}

Piglet growth and villous height of the small intestine regions of suckling piglets that received citrus extracts via pig doser or no additive it's presented in Table II. There was no difference $(P>0.05)$ between the treatments NC and EC for the number of piglets, litter weight and individual piglets' weight. The litters weight differed $(P<0.05)$ between $P O 3$ and $\mathrm{PO}>5$ sows, may be associated with the litters size and the individual weight of the piglets. This weight gain in piglets can be attributed to higher appetite, greater feed intake and subsequent milk production by older sows (> OP5). The higher volume of milk produced by older sows may explain the higher ADG in these categories during the lactation period [13]. Piglet mortality was $13.4 \%$ in piglets that not receive any medication (NC group) and $3.9 \%$ in 
the group of piglets that received solution of citrus extracts in a single dose on the third day of life. The lower mortality observed in piglets receiving citrus extracts may be associated with the effects of citral and linalool, as well as rutin and quercetin, which have immunostimulatory and antimicrobial actions in vitro $[14,15]$. Although in the literature we have not identified studies with citrus extracts for suckling piglets, several studies believe that bioactive compounds lead to decreased mortality of piglets during lactation, such as those extracted from plants such as carvacrol [3], cinnamaldehyde, thymol [16], fenugreek [17] which are known to have positive effects on gut health (microbiota and integrity), and immunity of suckling piglets.

Gut morphology in suckling piglets that received or not citrus extracts it's presented in Table II. The villous length in the duodenum was $24 \%$ higher $(P<0.01)$ in piglets receiving administration of citrus extracts. The villi in the jejunum not differ $(P>0.05)$ between NC and EC groups. The administration of citrus extracts increased $19 \%(P=0.02)$ the villous length of the ileum region of suckling piglets. The gut health of the suckling piglets is marked by the good development of the villi, use of the luminal nutrients and normal and stable microbioma [18]. In addition, the cellular differentiation of enterocytes and other epithelial cells in suckling piglets is modulated by volatile fatty acids concentrations in sow milk, type of diet and availability of luminal nutrients, essential for the gut health [19].

Table 2. Piglet growth and villous height of the small intestine regions of suckling piglets that received citrus extracts via pig doser or no additive

\begin{tabular}{|c|c|c|c|c|c|c|}
\hline & \multicolumn{2}{|c|}{ Treatments $(\mathrm{T})$} & \multicolumn{2}{|c|}{ Parity order (PO) } & \multicolumn{2}{|c|}{ Probability 1} \\
\hline & $\mathrm{NC}$ & $\mathrm{CE}$ & $\mathrm{PO} 3$ & $>$ PO5 & $\mathrm{T}$ & $\mathrm{PO}$ \\
\hline No. of litters & 10 & 10 & 8 & 12 & & \\
\hline \multicolumn{7}{|l|}{ No piglets } \\
\hline $\begin{array}{l}\text { After } \\
\text { cross-foster }\end{array}$ & $10.4 \pm 0.24$ & $10.2 \pm 0.58$ & $10.0 \pm 0.70$ & $10.4 \pm 0.22$ & ns & ns \\
\hline Weaned & $9.0 \pm 0.63$ & $9.8 \pm 0.49$ & $8.75 \pm 0.75$ & $9.88 \pm 0.40$ & ns & ns \\
\hline Mortality, \% & 13,4 & 3,92 & - & - & & \\
\hline \multicolumn{7}{|l|}{ Litter weight, kg } \\
\hline d 1 & $13.39 \pm 2.18$ & $13.18 \pm 0.88$ & $10.90 \pm 1.47$ & $14.87 \pm 1.25$ & ns & ns \\
\hline$d 7$ & $24.62 \pm 4.15$ & $24.75 \pm 1.45$ & $20.23 \pm 3.03$ & $27.66 \pm 2.19$ & ns & ns \\
\hline d 14 & $37.83 \pm 7.07$ & $42.54 \pm 2.49$ & $31.51 \pm 5.32$ & $45.97 \pm 3.35$ & ns & * \\
\hline d 21 & $53.48 \pm 8.80$ & $58.27 \pm 2.54$ & $45.19 \pm 6.23$ & $63.25 \pm 4.06$ & ns & * \\
\hline \multicolumn{7}{|l|}{ Body weight, kg } \\
\hline d 1 & $1.28 \pm 0.19$ & $1.30 \pm 0.07$ & $1.10 \pm 0.15$ & $1.30 \pm 0.11$ & ns & ns \\
\hline$d 7$ & $2.45 \pm 0.33$ & $2.55 \pm 0.09$ & $2.15 \pm 0.24$ & $2.65 \pm 0.16$ & ns & * \\
\hline d 14 & $4.10 \pm 0.46$ & $4.34 \pm 0.15$ & $3.70 \pm 0.35$ & $4.23 \pm 0.23$ & ns & ns \\
\hline d 21 & $5.40 \pm 0.64$ & $6.00 \pm 0.24$ & $5.16 \pm 0.60$ & $6.42 \pm 0.19$ & ns & * \\
\hline \multicolumn{7}{|l|}{$A D G, k g / d^{2}$} \\
\hline d 1 to 7 & $0.218 \pm 0.01$ & $0.200 \pm 0.02$ & $0.213 \pm 0.01$ & $0.205 \pm 0.02$ & ns & ns \\
\hline d 8 to 14 & $0.247 \pm 0.01$ & $0.198 \pm 0.01$ & $0.235 \pm 0.02$ & $0.210 \pm 0.01$ & * & ns \\
\hline d 15 to 21 & $0.246 \pm 0.01$ & $0.192 \pm 0.02$ & $0.234 \pm 0.01$ & $0.204 \pm 0.02$ & * & ns \\
\hline \multicolumn{7}{|c|}{ Villus height, mm } \\
\hline Duodenum & $0.320 \pm 0.02$ & $0.398 \pm 0.01$ & $0.315 \pm 0.02$ & $0.373 \pm 0.01$ & $* *$ & ns \\
\hline Jejunum & $0.420 \pm 0.02$ & $0.419 \pm 0.02$ & $0.394 \pm 0.01$ & $0.440 \pm 0.02$ & ns & ns \\
\hline Ileum & $0.242 \pm 0.01$ & $0.288 \pm 0.01$ & $0.272 \pm 0.01$ & $0.255 \pm 0.01$ & * & ns \\
\hline
\end{tabular}

Mean \pm standard error; NC: Negative Control; CE: Citrus Extracts; ${ }^{1} \mathrm{Ns} P>0.05$; ${ }^{*} \mathrm{P} \leq 0.05$;

${ }^{* *} \mathrm{P} \leq 0.005 ;{ }^{* * *} \mathrm{P} \leq 0.001 .{ }^{2}$ Number of piglets / sows used as covariate, adjusted LSM mean. 


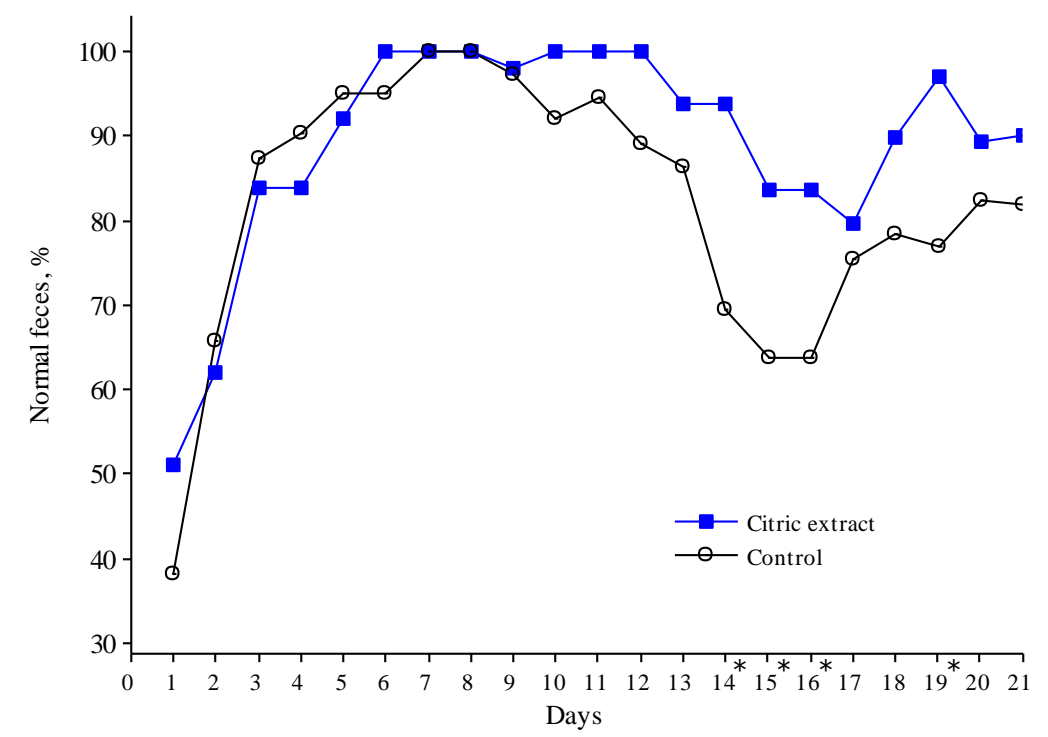

Figure 1. Frequency of normal feces in suckling piglets with oral administration of citrus extracts. ${ }^{*}$ differ by the Tukey test $(P<0.05)$.

Another few discussions are the variability among suckling pigs that pre-initial feed intake, which alters the structure of the villous in the gastrointestinal tract [20]. Zhai, et al. [5], in a systematic review, indicate that the benefits of bioactive compounds present in plants, seeds and fruits present variable responses on the gut morphology of piglets. Hanczakowska et al. [21], added a liquid mixture of flower extracts and Sicilian lemon in the pre-initial diet of suckling piglets and verified higher villous height in the jejunum and ileum.

The frequency of normal feces was higher $(\mathrm{P}<0.05)$ in piglets $E C$ group (Figure I). The liquid feces verified in the first three days are associated to the excess of milk intake and probably its low use for gut microbiota of piglets in early-life. Diarrhea caused by Escherichia coli shows yellowish color and pasty to liquid consistency. In this study we considered normal feces, those with dark coloration and dry and firm consistency. The low production of hydrochloric acid and the buffering capacity of pre starter diets for suckling piglets, compromise the digestion of nutrients, and this increases the amount of substrate for the pathogenic bacteria occurs [22,23]. The antimicrobial action of plant extracts is still little known, but it is suggested that terpenoids, phenolic compounds and alkaloids, besides the chelation of metals by flavonoids can inhibit the growth of gut microorganisms [24].

Several studies show that bioactive compounds reduce the diarrhea rate in suckling and nursery piglets such as red pepper oil [25], garlic, pepper and saffron oleoresins [26], oregano oil and rosemary [4] can modulate the gut microbiota through selectivity $[5,19]$. However, the flavonoids present in the citrus extracts have a low $\mathrm{pKa}$, not acting in $\mathrm{pH}$ acidification, but are terpenoids that act directly on the lipid membranes of gram-positive bacteria [15], and can act selectively on the gut microflora. Parity order may also interfere in piglet's immunity, differing especially between primiparous and multiparous sows [4]. In this study, only sows with a higher parity order than OP3 were used, therefore, the effect of immune efficiency on the litters can be ignored. Although many studies point to positive effects of plant bioactive compounds, [27] indicate that antimicrobials even better results in gut health and piglet's performance in relation to plant extracts.

In this study, oral antibiotics were not used, but in both treatments, the pre-starter diet was commercial and contained antibiotics, can be interfere in responses. The continuous use of antibiotics in the diet of piglets does not alter intestinal integrity and piglet growth when there is no environmental challenge [28]. However, plant extracts in diets for piglets are effective when the animal is undergoing a sanitary challenge [29]. Currently, several bioactive compounds of plant extracts have been studied as alternatives to the use of 
antimicrobials in pre-starter diets. As for flavonoids from citrus fruits, studies are yet incipient.

\section{CONCLUSION}

Oral administration of citrus extracts containing flavonoids and ascorbic acid to suckling piglets not improves the piglet growth. However, it alters the gut morphology, and reduces the frequency of diarrhea during suckling period. Parity order interferes on feed intake, feed conversion of sows and performance of litters.

Acknowledgments: To the National Council for Scientific Technology and Development (CNPq), to the Coordination for Improvement in Higher Education Personnel (Capes) and the Araucaria Foundation for grants awarded.

Conflicts of Interest: The authors declare no conflict of interest.

\section{REFERENCES}

1. Markus R, Lankveld A Van. Antibiotic-free. The European experience. Herzogenburg, Austria; 2014. Available from:

https://www.biomin.net/uploads/tx_news/ART_No37_S_EN_0514_RMR.pdf.

2. Silvia EN. Antibióticos intestinais naturais: bacteriocinas. In: Simpósio sobre Aditivos

Alternativos na Nutrição Animal. 2000. p. 15-24.

3. Ariza-Nieto C, Bandrick M, Baidoo SK, Anil L, Molitor TW, Hathaway MR. Effect of dietary supplementation of oregano essential oils to sows on colostrum and milk composition, growth pattern and immune status of suckling pigs1. Journal of Animal Science. Oxford University Press; 2011 Apr 1; 89(4):1079-89. Available from: http://academic.oup.com/jas/article/89/4/1079/4764112

4. Rossi CA, Soares M, Luchese FC, Santurio JM. Uso de óleos essenciais no controle dos sinais clínicos das diarreias neonatais em leitões nascidos de fêmeas com diferentes ordens de parto. Ciência Animal Brasileira. 2015 Mar; 16(1):93-102. Available from: http://www.scielo.br/scielo.php?script=sci_arttext\&pid=S1809-68912015000100093\&lng=pt\&tln $\mathrm{g}=\mathrm{pt}$

5. Zhai H, Liu H, Wang S, Wu J, Kluenter A-M. Potential of essential oils for poultry and pigs. Animal Nutrition. Elsevier; 2018 Jun 1;4(2):179-86. Available from: https://www.sciencedirect.com/science/article/pii/S2405654517301506

6. Aranha FQ, Barros ZF, Moura LSA, Gonçalves M da CR, Barros JC de, Metri JC, et al. O papel da vitamina $C$ sobre as alterações orgânicas no idoso. Rev Nutr. 2000 Aug; 13(2):89-97. Available from:

http://www.scielo.br/scielo.php?script=sci_arttext\&pid=S1415-52732000000200003\&lng=pt\&tln $\mathrm{g}=\mathrm{pt}$

7. Wang R, Li D, Bourne S. Can 2000 years of herbal medicine history help us solve problems in the year 2000. In: Alltechs Annual Symposium. 1998. p. 168-184.

8. Young M, Aherne F. Monitoring and Maintaining Sow Condition. Adv Pork Prod. 2005; 16:299-313. Available from: http://www.prairieswine.com/pdf/2465.pdf

9. SAS Inc. Statistical Analysis System. Cary, NC; 2008.

10. Minitab Inc. Minitab 15. 2007.

11. Lavery A, Lawlor PG, Magowan E, Miller HM, O'Driscoll K, Berry DP. An association analysis of sow parity, live-weight and back-fat depth as indicators of sow productivity. animal [Internet]. Cambridge University Press; 2019 Mar 18; 13(3):622-30. Available from: https://www.cambridge.org/core/product/identifier/S1751731118001799/type/journal_article

12. Young MG, Tokach MD, Aherne FX, Main RG, Dritz SS, Goodband RD, et al. Effect of sow parity and weight at service on target maternal weight and energy for gain in gestation. Journal of Animal Science. 2005 Jan; 83 (1):255-61. Available from: http://www.ncbi.nlm.nih.gov/pubmed/15583066 
13. Beyer M, Jentsch W, Kuhla S, Wittenburg H, Kreienbring F, Scholze H, et al. Effects of dietary energy intake during gestation and lactation on milk yield and composition of first, second and fourth parity sows. Archivos of Animal Nutrition. 2007 Dec 15; 61 (6):452-68. Available from: http://www.ncbi.nlm.nih.gov/pubmed/18069617

14. Fisher K, Phillips CA. The effect of lemon, orange and bergamot essential oils and their components on the survival of Campylobacter jejuni, Escherichia coli O157, Listeria monocytogenes, Bacillus cereus and Staphylococcus aureus in vitro and in food systems. Journal of Applied Microbiology. John Wiley \& Sons, Ltd (10.1111); 2006 Dec 1; 101(6):1232-40. Available from: http://doi.wiley.com/10.1111/j.1365-2672.2006.03035.x

15. Lee JH, Cho S, Paik HD, Choi CW, Nam KT, Hwang SG, et al. Investigation on Antibacterial and Antioxidant Activities, Phenolic and Flavonoid Contents of Some Thai Edible Plants as an Alternative for Antibiotics. Asian-Australasian Journal of Animal Science. 2014 Aug 20; 27(10):1461-8. Available from: http://ajas.info/journal/view.php?doi=10.5713/ajas.2013.13629

16. Matysiak B, Jacyno E., Kawęcka M., Kotodziej-Skalska A., Pietruszka A. The effect of plant extracts fed before farrowing and during lactation on sow and piglet performance. South African Journal of Animal Science. 2012 Jan; 42(1): 15-21. Available from:

http://www.scielo.org.za/scielo.php?script=sci_arttext\&pid=S0375-15892012000100002\&lng=e n.

17. Hossain MM, Begum M, Nyachoti CM, Hancock JD, Kim IH. Dietary fenugreek seed extract improves performance and reduces fecal E. coli counts and fecal gas emission in lactating sows and suckling piglets. Canadian J Animal Science. Agricultural Institute of Canada; 2015 Dec; 95(4):561-8. Available from: http://www.nrcresearchpress.com/doi/10.4141/cjas-2014-154

18. Pluske JR, Turpin DL, Kim J-C. Gastrointestinal tract (gut) health in the young pig. Animal Nutrition. Elsevier; 2018 Jun 1; 4(2):187-96. Available from: https://www.sciencedirect.com/science/article/pii/S2405654517301920

19. Wang J, Ji H, Wang S, Liu H, Zhang W, Zhang D, et al. Probiotic Lactobacillus plantarum Promotes Intestinal Barrier Function by Strengthening the Epithelium and Modulating Gut Microbiota. Front Microbiol. Frontiers; 2018 Aug 24; 9:1953. Available from: https://www.frontiersin.org/article/10.3389/fmicb.2018.01953/full

20. Hedemann MS, Dybkjær L, Jensen BB. Pre-weaning eating activity and morphological parameters in the small and large intestine of piglets. Livestock Science. Elsevier; 2007 May 1; 108(1-3):128-31. Available from: https://www.sciencedirect.com/science/article/abs/pii/S1871141307000236?via\%3Dihub

21. Hanczakowska E, Swiatkiewicz M. Effect of herbal extracts on piglet performance and small intestinal epithelial villi. Vol. 57, Original Paper Czech J. Anim. Sci. Available from: https://www.agriculturejournals.cz/publicFiles/71986.pdf

22. Canibe N, Jensen BB. Fermented and nonfermented liquid feed to growing pigs: Effect on aspects of gastrointestinal ecology and growth performance. Journal of Animal Science. Oxford University Press; 2003 Aug 1; 81(8):2019-31. Available from: https://academic.oup.com/jas/article/81/8/2019/4790105

23. Walsh MC, Peddireddi L, Radclife JS. Acidification of nursery diets and the role of diet buffering capacity. Swine Res Rep. 2004; 25-36.

24. Negi PS. Plant extracts for the control of bacterial growth: Efficacy, stability and safety issues for food application International Journal of Food Microbiology. Elsevier; 2012 May 1; 156(1):7-17. Available from: https://www.sciencedirect.com/science/article/pii/S0168160512001250

25. Cairo PLG, Gois FD, Sbardella M, Silveira H, de Oliveira RM, Allaman IB, et al. Effects of dietary supplementation of red pepper (Schinus terebinthifolius Raddi) essential oil on performance, small intestinal morphology and microbial counts of weanling pigs. Journal of the Science of Food and Agriculture. John Wiley \& Sons, Ltd; 2018 Jan 1; 98(2):541-8. Available from: http://doi.wiley.com/10.1002/jsfa.8494

26. Liu Y, Song M, Che TM, Almeida JAS, Lee JJ, Bravo D, et al. Dietary plant extracts alleviate diarrhea and alter immune responses of weaned pigs experimentally infected with a pathogenic Escherichia coli. Journal Animal Science. Oxford University Press; 2013 Nov 1; 91(11):5294-306. Available from: https://academic.oup.com/jas/article/91/11/5294/4731434 
27. Zangeronimo MG, Cantarelli V de S, Fialho ET, Amaral N de O, Silveira H, Pereira L de M, et al. Herbal extracts and symbiotic mixture replacing antibiotics in piglets at the initial phase. Revista Brasileira de Zootecnia. Sociedade Brasileira de Zootecnia; 2011 May; 40(5):1045-51. Available from:

http://www.scielo.br/scielo.php?script=sci_arttext\&pid=S1516-35982011000500016\&lng=en\&tl $\mathrm{ng}=\mathrm{en}$

28. Adewole DI, Kim IH, Nyachoti CM. Gut Health of Pigs: Challenge Models and Response Criteria with a Critical Analysis of the Effectiveness of Selected Feed Additives - A Review.

Asian-Australasian Journal of Animal Science. Asian-Australasian Association of Animal Production Societies (AAAP); 2016 Jul; 29(7):909-24. Available from: http://www.ncbi.nlm.nih.gov/pubmed/26954144

29. Kommera SK, Mateo RD, Neher FJ, Kim SW. Phytobiotics and Organic Acids as Potential Alternatives to the Use of Antibiotics in Nursery Pig Diets. Asian-Australasian Journal of Animal Science. 2006 Sep 29; 19(12):1784-9. Available from:

http://ajas.info/journal/view.php?doi=10.5713/ajas.2006.1784

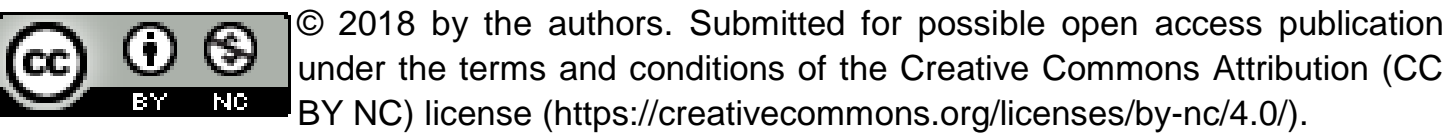

